19 Revue d'histoire du XIXe siècle

Société d'histoire de la révolution de 1848 et des

révolutions du XIXe siècle

$9 \mid 1993$

Utopies au XIXe siècle

\title{
De l'utopie de Jeanne Deroin
}

Michèle Riot-Sarcey

OpenEdition

Journals

Electronic version

URL: http://journals.openedition.org/rh19/67

DOI: $10.4000 /$ rh 19.67

ISSN: $1777-5329$

Publisher

La Société de 1848

Printed version

Date of publication: 1 June 1993

ISSN: 1265-1354

Electronic reference

Michèle Riot-Sarcey, « De l'utopie de Jeanne Deroin », Revue d'histoire du XIXe siècle [Online], 9| 1993, Online since 09 September 2008, connection on 19 April 2019. URL : http://journals.openedition.org/ rh19/67 ; DOI : 10.4000/rh19.67

This text was automatically generated on 19 April 2019

Tous droits réservés 


\title{
De l'utopie de Jeanne Deroin
}

\author{
Michèle Riot-Sarcey
}

\section{ABSTRACTS}

No abstract available by now

Pas de résumé disponible actuellement

INDEX

Mots-clés: Histoire politique, Socialisme, Utopie 